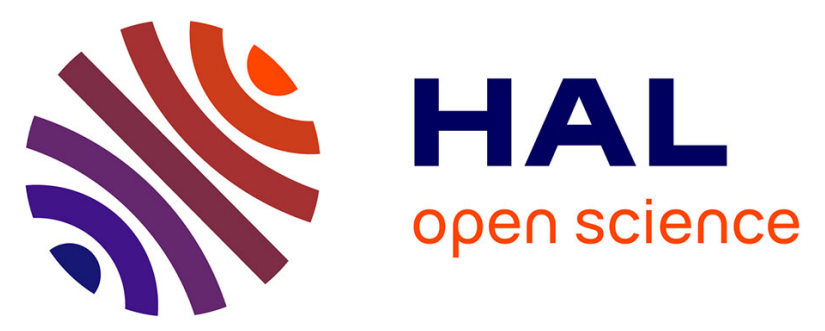

\title{
New insights into the recent eruptive history of Montagne Pelée (Lesser Antilles Arc) from offshore marine drilling site U1401A (IODP Expedition 340)
}

Clara Solaro, Georges Boudon, Anne Le Friant, Hélène Balcone-Boissard, Laurent Emmanuel, Martine Paterne

\section{To cite this version:}

Clara Solaro, Georges Boudon, Anne Le Friant, Hélène Balcone-Boissard, Laurent Emmanuel, et al.. New insights into the recent eruptive history of Montagne Pelée (Lesser Antilles Arc) from offshore marine drilling site U1401A (IODP Expedition 340). Journal of Volcanology and Geothermal Research, 2020, 403, pp.107001. 10.1016/j.jvolgeores.2020.107001 . hal-03014565

\section{HAL Id: hal-03014565 \\ https://hal.science/hal-03014565}

Submitted on 19 Nov 2020

HAL is a multi-disciplinary open access archive for the deposit and dissemination of scientific research documents, whether they are published or not. The documents may come from teaching and research institutions in France or abroad, or from public or private research centers.
L'archive ouverte pluridisciplinaire HAL, est destinée au dépôt et à la diffusion de documents scientifiques de niveau recherche, publiés ou non, émanant des établissements d'enseignement et de recherche français ou étrangers, des laboratoires publics ou privés. 
New insights into the recent eruptive history of Montagne Pelée (Lesser Antilles arc) from offshore marine drilling site U1401A (340 Expedition IODP)

4

5 Clara Solaro a , Georges Boudon a , Anne Le Friant a , Hélène Balcone-Boissard b, 6 Laurent Emmanuel ${ }^{\mathrm{b}}$, Martine Paterne ${ }^{\mathrm{c}}$, and IODP Expedition Science Party 7 8

9 a Université de Paris, Institut de physique du globe de Paris, CNRS, F-75005 Paris, France.

b Sorbonne Université, Institut des Sciences de la Terre de Paris (ISTeP), UMR 7193, 4 place

11 Jussieu, 75005 Paris, France.

$12{ }^{c}$ LSCE, - UMR 8212 - CEA-CNRS UVSQ/IPSL, Avenue de la Terrasse, Domaine du CNRS, 13 91198 Gif Sur Yvette Cedex - France

14

15

Key words : Montagne Pelée, Tephrochronology, eruptive history, flank-collapse, IODP expedition 340

20

Corresponding author: Georges Boudon (boudon@ipgp.fr)

23 Université de Paris, Institut de physique du globe de Paris, CNRS, F-75005 Paris, France. 
27 Marine tephrochronology provides a good alternative to study in depth the eruptive history of volcanic islands in a tropical climate and overcome the problem of poorly preserved outcropping. Here, we provide new observations on the recent volcanological evolution $(<40$ kyrs) of Montagne Pelée (Martinique Lesser Antilles) based on the tephrochonological study of a marine core from the site U1401, sampled during the 340 IODP expedition and located $28 \mathrm{~km}$ from the coastline, west off Martinique Island. The core (15 $\mathrm{m}$ recovered length) was obtained from the debris avalanche deposits (DAD) due to the last flank collapse that occurred on Montagne Pelée volcano. Although it was not possible to drill through the DAD because of the heterogeneity of the deposit and the presence of large blocks, the sediments and volcanic deposits that covered the DAD were sampled. A detailed multiparameter study (geophysical data acquired on-board during the IODP cruise, lithological and geochemical data and temporal constrains through ${ }^{18} \mathrm{O}$ stratigraphy and ${ }^{14} \mathrm{C}$ dating) of the core U1401A suggest a new age for the last flank collapse leading us to update the volcanological recent history of Montagne Pelée. The last flank collapse is now dated at $\sim 36$ cal. ka BP (older than previous studies). The flank collapse, even though it wasn't voluminous $\left(2 \mathrm{~km}^{3}\right)$, had a significant consequence on the magma plumbing system of Montagne Pelée and produced, by the threshold effect exerted on the plumbing system, abundant explosive eruptions with basaltic-andesite magmas, during the period 36-25 cal. ka BP. This new age obtained for this flank collapse has important implications not only for the post collapse activity, but also allows us to rethink the recent volcanological history of Montagne Pelée.

\section{Introduction}


The reconstruction of the eruptive history of a volcano relies mainly on historical chronicles and on geological studies of volcanic deposits in order to establish the most comprehensive stratigraphy. Geological studies face many problems, the first of which being the adequate preservation of key outcrops. This issue is of prime importance particularly in tropical environment where high precipitation rates and alteration processes destroy large proportions of volcanic deposits and abundant vegetation impairs on-land observations.

56 Considering all these parameters and the recovery from eruptive products, it is difficult to achieve a detailed stratigraphy that stretches beyond a few thousand years. In a volcanic island context, to overcome this problem and go into further detail, marine tephrochronology provides a good alternative to complete the volcanological history for earlier periods. Reconstruction of volcanic activity and history have already been carried out on several volcanoes, using both marine or lacustrine tephrochronological data and on-land stratigraphy (Sigurdsson and Carey, 1981; Paterne et al., 1988; 1990, 2008; Wulf et al., 2004; Shane, 2000; Shane et al., 2006; Le Friant et al., 2008; Allan et al., 2008; Engwell et al, 2014; Jennings et a., 2014; Lowe, 2014; Weller et al., 2015).

In recent decades several cruises (Aguadomar-1999, Caraval-2002, JCR-2005, Gwadaseis-2009) have taken place off the Lesser Antilles islands. Geophysical data were acquired, and several piston cores were also sampled. The first meters of sediments have been documented and thus completing part of the volcanological history of some volcanoes such as Soufrière Hills volcano (Trofimovs et al. 2006; Le Friant et al., 2008; Wall-Palmer et al., 2012) or Montagne Pelée (Boudon et al., 2013). Deep drilling projects provide a unique opportunity to investigate sediments found several hundred meters deep and the volcanoclastic deposits from the surrounding volcanoes, sometimes going back several million years (Kutterolf et al., 2018). The 340 IODP Expedition (March-April 2012) aboard the Joides Resolution, drilled a series of sites offshore Montserrat, Martinique and Dominica 
(Fig. 1a). The objectives of the project were 1/ to characterize the voluminous chaotic units identified off the islands associated with the volcanic island landslides (Brunet et al., 2016; Le Friant et al., 2015); 2/ to obtain a complete volcanological history of the surrounding volcanoes and to include the large mass wasting events in the evolution of the volcanoes (Wall-Palmer et al., 2014; Cassidy et al., 2015; Coussens et al., 2016)

The aim of this paper is to provide new insights on the last tens of thousands of years of Montagne Pelée's evolution based on the tephrochonological study of site U1401, sampled during the 340 IODP expedition and located west off Martinique Island, $28 \mathrm{~km}$ from the coastline (Fig.1b). By drilling through the DAD the objectives were to characterize and date the setting of the debris avalanche with associated erosional processes. Although it was not possible to drill through the DAD because of the heterogeneity of the deposit and the presence of large blocks (Le Friant et al., 2015), the pelagic sediments and volcanic deposits that covered the DAD were successfully sampled. They thus offer a good opportunity to study the post DAD volcanoclastic sedimentation processes and to better constrain the volcano's recent evolution.

\section{Geological setting}

Martinique Island is located in the southern part of the Lesser Antilles arc that result from the subduction of the northern and southern Atlantic plates beneath the Caribbean plate with a relatively slow rate of $2 \mathrm{~cm} / \mathrm{yr}$ (Wadge, 1984). This southern part of the arc is bordered to the west by the $3000 \mathrm{~m}$ deep back-arc Grenada Basin (Fig. 1a). Montagne Pelée, the sole active volcano of Martinique island and one of the twelve active volcanoes of the arc, is located in 
100 the northern part of Martinique, north of the old Morne Jacob - Pitons du Carbet volcano,

101 (Fig. 1b). It is a famous and tragic volcano as during the first months of the 1902-1905 dome102 forming eruption the towns of St. Pierre and Morne Rouge were destroyed by a series of 103 laterally directed explosions killing 30000 inhabitants (Lacroix, 1904). The last eruptive 104 activity was the 1929-1932 lava dome-forming eruption (Perret, 1937).

106 Previous works: In the last decades and especially after the 1902-1905 eruption a lot of 107 studies were carried out on Montagne Pelée. Exclusively terrestrial studies were performed 108 until 1998 (Roobol and Smith, 1976; Westercamp and Traineau, 1983a, b; Bourdier et al., 109 1985, 1989; Boudon and Lajoie, 1989; Boudon, 1993) whereas, after this date, combined on110 land and marine data were obtained through several cruises, field work and laboratory studies 111 (Deplus et al., 2001; Le Friant et al., 2003, 2015; Boudon et al., 2005, 2007, 2013; Brunet et 112 al., 2016).

113 Based on previous works, the volcanological evolution of Montagne Pelée was divided in 114 three eruptive phases. The first two phases ended in a large flank collapse. (Fig. 1c, Le Friant 115 et al., 2003; Boudon et al., 2005, 2007, 2013; Brunet et al., 2016).

116 The first eruptive phase resulted in a first volcanic edifice that was destroyed by a large flank 117 collapse (Le Prêcheur event) that produced a 8 × $6 \mathrm{~km}$ large horseshoe-shaped structure 118 (without the invisible southern rim) and a debris avalanche of $\sim 25 \mathrm{~km}^{3}$ that flowed into the 119 Grenada basin (Le Friant et al., 2003; Boudon et al., 2007). Using K-Ar ages acquired from 120 lava domes and lava flows on the northern volcanic edifices of Montagne Pelée and Mont 121 Conil this event was dated at $127 \mathrm{ka}$ (Germa et al., 2011a).

122 The second eruptive stage created a new volcanic edifice inside and on the southern rim 123 of the first flank-collapse structure. Dome-forming eruptions and associated block- and ash 124 pyroclastic density currents involving acid magmas were the dominant activity of this period. 
125 This volcanic edifice was destroyed by a second flank collapse (St Pierre event), which 126 generated a horseshoe-shaped structure, $6 \times 4 \mathrm{~km}$ in size, and a debris avalanche $\left(\sim 13 \mathrm{~km}^{3}\right)$ 127 that flowed like the first one into the Grenada basin. By correlating stratigraphy and 128 magmatology of on-land deposits with tephra layers identified in a piston core (CAR-MAR 4) 129 drilled during the Caraval cruise northwest of Martinique (Fig. 1a), Boudon et al. (2013) 130 proposed a minimum age of $32 \mathrm{ka}$ cal BP for this flank collapse.

131 The third eruptive stage, just after this flank collapse, generated more basic magmas 132 (basaltic andesite), with a high production rate, over several thousand years. After a decrease 133 in the magma production, activity resumed and the magma emitted, after and up to the 134 historic activity of Montagne Pelée, were again as acid as during the second eruptive stage. 135 Plinian to subplinian events and dome-forming eruptions were the two main eruptive styles that occurred during this period. On-land studies recognized 10 plinian to subplinian events and 18 dome-forming eruptions, including the two last historic eruptions, during the last 15 000 years of eruptive activity (Roobol and Smith, 1976; Westercamp and Traineau, 1983a, b;

139 Traineau et al., 1989; Smith and Roobol, 1990; Michaud-Dubuy, 2019). But 140 tephrochronological studies of the CAR-MAR 4 piston core showed that the number of 141 volcanic events identified on-land was underestimated particularly for the period prior to 1425000 years BP (Boudon et al., 2013).

143 During this third stage, a new flank-collapse occurred on the southwestern flank of the 144 volcano (Rivière Sèche event). Lower in volume than the previous ones $\left(\sim 2 \mathrm{~km}^{3}\right)$, the debris 145 avalanche flowed and stopped at the base of the submarine flank and exhibits a typical 146 hummocky morphology. U-Th dating on lava dome located inside the structure gives an age 147 of $\sim 9 \mathrm{ka}$ for this event (Le Friant et al., 2003).

148 On the basis on IODP core analysis, Le Friant et al. (2015) and Brunet et al. (2016) stated 149 that for the first flank collapse affecting Montagne Pelée volcano the debris avalanche entered 
150 the sea, flowed over the submarine volcano slope, to stop and deposit around the slope break.

151 This first - and the largest - debris avalanche deposit loaded, weakened seafloor sediment.

152 Resulting submarine landslide propagates along a decollement surface, deforming in situ

153 alternation of hemipelagic sediments and turbidity deposits (Fig 1b). The debris avalanche

154 deposit generated by the second flank collapse may have locally remobilized sediments within

155 the submarine landslide deposit, by exerting normal stress that triggered the deformation 156 process.

\section{Materials and analytical methods}

\subsection{Coring and on-board observations}

The site U1401 consists of four different holes drilled along a transect $900 \mathrm{~m}$ long, NW-

164 SE direction, above the debris avalanche deposits (DAD) associated with the last flank 165 collapse generated by Montagne Pelée volcano (Fig. 1b). The hole U1401A, (14³9.10’N, $\left.61^{\circ} 25.08^{\prime} \mathrm{W} ; 2590 \mathrm{mbsl}\right)$, is the longest of the four drilled holes at $15.61 \mathrm{~m}$ recovered length, and has been chosen for this study. For each hole (example: U1401A), several $9 \mathrm{~m}$ long cores were collected (example U1401A-1H) and were cut in sections with a maximum length of 1.5 m (example: U1401A - 1H1). Each section was sawn lengthwise. One half was stored as an archive (GCR - USIO, Texas A \& M University College Station, Gulf Coast Repository)

171 and the other half was used for physical properties (magnetic susceptibility, gamma-ray attenuation density, P-wave velocity), chemical analysis and lithological descriptions. On-

173 board each core was precisely described by sedimentologists and volcanologists in terms of 174 sedimentology, lithology and volcanic structures. 
For specific analysis, samples were taken according to their position in each section of

179 the core (example U1401A - 1H4, 93/95cm). A systematic sampling (every $10 \mathrm{~cm}$ ) of the

180 hemipelagic sediments was carried outall along the core for $\delta^{18} \mathrm{O}$ chronostratigraphy. For 181 lithological and chemical analyses of volcanic deposits, samples were taken from each deposit 182 that was visually identified within the core. In case of thick turbidity deposit, two or three 183 samples were taken, at the base, the middle and the top of the deposit, to observe potential 184 lithological variations.

\subsection{On board physical properties}

Magnetic susceptibility measurements were realized with the multisensor track (MST) aboard the Joides Resolution. Closely spaced measurements (one point every $3 \mathrm{~cm}$ ) were collected on the four cores of the site U1401. Magnetic susceptibility measurements provide

191 information on the content of magnetic minerals of each measured lithological level. Thus it 192 is possible to distinguish hemipelagic mud, characterized by a low amount of magnetic and 193 paramagnetic particles, from tephra layers and volcanic turbidity deposits, significantly enriched with magnetic particles.

195 Gamma - ray attenuation density measurements were performed with the DSDP GRAPE 196 hardware and software. The system consists of a specific instrument that moves a section of 197 core in between a gamma-ray source and a detector. Measurements are based on the direct 198 correlation between the gamma-ray attenuation and the bulk density of the sample, which is 
an indicator of lithological changes (minerals, grain size, porosity). The higher the bulk density of the sample is, the higher is the attenuation.

Physical properties data need to be corrected due to data related to technical problems occurring during measurements when moving from one section to another (i.e. aberrant density values lower than $1 \mathrm{~g} / \mathrm{cm}^{3}$ ). For this reason, acquired measurements on a slice of 20 $\mathrm{cm}$ at the boundary between two successive sections were systematically removed.

We focused on magnetic susceptibility data as they exhibit more sensitive variations along the core. Detailed information about lithological changes at a small scale (1 to $10 \mathrm{~cm})$ and identification of tephra layers within each section can be obtained using this dataset.

\section{4. ${ }^{18}$ O stratigraphy}

To assess chronology of the volcanic deposits, hemipelagic sediment was sampled every $10 \mathrm{~cm}$ all along the core. However, the presence of thick turbidity deposits prevented us from keeping a constant sampling interval all along the core. Turbidity deposits will be taken into 214 account in the interpretation of $\delta^{18} \mathrm{O}$ curves. After being dried for about 12 hours at $70^{\circ} \mathrm{C}$, each sample was divided in two equal parts, one used for measurements and the other saved as an archive. The former fraction was then weighed, sieved under water in a $40 \mu \mathrm{m}$ stainless steel sieve to remove fine particles, then dried again and finally weighed a second time. This

218 fraction was then divided in two halves, one for $\delta^{18} \mathrm{O}$ chronostratigraphy and ${ }^{14} \mathrm{C}$ dating, the 219 second for lithological and mineralogical analysis.

220 For $\delta^{18} \mathrm{O}$ chronostratigraphy, 3 to 4 planktotic foraminifera from the specific species of 221 Globigerinoides ruber (Alba White, D’Orbigny, 1839) were hand-picked in the fraction 250$222315 \mu \mathrm{m}$. Isotopic $\delta^{18} \mathrm{O}$ analyses of foraminifera samples were performed at ISTeP (Sorbonne 223 Université), with a 3kV-Delta V Advantage IRMS attached to a Kiel IV Carbonate Device. 
224 Isotope values are reported in conventional delta $(\delta)$ notation as per mil (\%o) deviations of the

225 isotopic ratios $\left({ }^{18} \mathrm{O} /{ }^{16} \mathrm{O}\right)$ calculated to the VPDB scale using an inhouse standard (Carrara

226 Marble) calibrated against NBS-19. Standard deviation $(1 \sigma)$ for $\delta^{18} \mathrm{O}$ measurements is 0.07 $227 \%$.

4.5. ${ }^{14}$ C dating

On the basis of the $\delta^{18} \mathrm{O}$ curve, ${ }^{14} \mathrm{C}$ dates allow us to obtain absolute ages on key points of

232 the curve to "calibrate" the timescale. For ${ }^{14} \mathrm{C}$ dating, 1000 planktonic foraminifera (about 14 $233 \mathrm{mg}$ required for spectrometer detection limit) were hand-picked in the fraction $250-315 \mu \mathrm{m}$ of 234 each sample. The ${ }^{14} \mathrm{C}$ analyses were performed at the French National AMS-ARTEMIS235 LMC14 facility (Artemis Accelerator Mass Spectrometer, Saclay Laboratory, Université 236 Paris-Saclay, France). The ${ }^{14} \mathrm{C}$ dating have been converted into calendar years using the Intcal 23709 calibration record (Reimer et al., 2009; Hughen et al., 2004) taking into account the marine 238 reservoir age correction of 400 years.

4.6. Lithological data

Lithologic analyses of turbidity deposits and tephra layers were performed on selected samples, chemically attacked with $\mathrm{HCl}(0.1 \mathrm{~mol})$ to disaggregate all carbonate microfossils 244 and carbonate non biogenic particles, rinsed with de-ionized water, dried and weighed. To remove all remnant fine particles, samples were then sieved in de-ionized water with a $40 \mu \mathrm{m}$ stainless steel sieve, dried again for about 24 hours at $70^{\circ} \mathrm{C}$, and weighed a second time. Each

247 sample was divided in two equal parts, one fraction used for lithology and the other for 248 geochemistry. Counting for lithology was done on 46 samples on the fraction $>125 \mu \mathrm{m}$ on a 
basis of at least 400 particles/sample on a quadri plate under a binocular microscope. Five

250 classes of clasts were identified: pumice and glass shard particles, scoria clasts, lava dome 251 clasts, oxidized and hydrothermalized clasts and crystals (feldspars, orthopyroxenes, 252 clinopyroxenes, amphiboles, oxides). The objective of counting is to identify the peak of 253 abundance of the different volcanic clasts (scoria, pumice or lava domes clasts); They allow 254 us to link the deposit to a specific eruptive style (pumices with plinian eruptions, scorias with 255 explosive eruptions with more basic magma, and dense clasts with lava dome eruptions) and 256 find some benchmark levels in the core. Counting precision has been estimated counting 6 257 times 6 different samples. The error linked to the operator is of about $10 \%$ based on the 258 counting of the same sample by three different operators. The background signal was 259 estimated counting about 400 clasts in some hemipelagic fractions of the core.

260 Moreover, detailed textures of volcanic clasts (vesicularity, microcristallinity) have been 261 investigated using Back-Scattered Electron (BSE) images of pumice, scoria and lava dome 262 clasts with a ZEISS-Supra 55 SEM (ISTeP, Sorbonne Université, Paris). Imaging was 263 performed with an acceleration voltage of $15 \mathrm{kV}$ and a probe current of $5 \mathrm{nA}$.

\subsection{Geochemical data: glass composition}

Pumice and scoria clasts from each peak of abundance along the core were hand-picked in the sample fraction reserved for geochemistry, embedded in resin and polished. Major 269 element composition of matrix glass was determined in 10 different tephra layers and 10 turbiditic levels using a CAMECA-SX 100 electron microprobe (Service Camparis, Paris,

271 France). Analyses were performed with an acceleration voltage of $15 \mathrm{kV}$ and a beam current 272 of $4 \mathrm{nA}$. Counting time was of $5 \mathrm{~s}$ on $\mathrm{Na}$ to limit $\mathrm{Na}$ migration, 10 s for $\mathrm{Si}, \mathrm{Ti}, \mathrm{Al}, \mathrm{Fe}$, $273 \mathrm{Mn}, \mathrm{Mg}, \mathrm{Ca}, \mathrm{K}, \mathrm{P}$ and $15 \mathrm{~s}$ for $\mathrm{Cl}$. As recommended, we analyzed a minimum of 20 different 
274 glass shards per level. However, depending on the level, between 5 and 30 glass shards were

275 kept after detailed investigations of glass composition to discard analyses that represent bias 276 data due to microlite composition.

277 The purpose of analysing chemical composition of pumice and scoria peaks is to 278 precisely identify the chemical composition of tephra along the core in order to compare them 279 with those of on-land products known for recent Montagne Pelée activity (Westercamp and 280 Traineau, 1983b; Fichaut et al., 1989). No data has been acquired on lava dome clasts since 281 they are too microcrystallized.

\section{Results}

\subsection{Core description}

Cores from hole U1401A, $15.61 \mathrm{~m}$ long, were described using core logs and photos obtained on-board during the cruise. The close-up photograph of the section U1401A-1H and a synthetic core description of the whole core are presented in Fig. 2. It consists of a series of volcanoclastic sediments intercalated in hemipelagic mud made of silt and clays (Fig. 2a). We can distinguish two types of volcanoclastic deposits: volcanoclastic turbidity deposits and tephra layers.

294 Turbidity deposits are a few tens of centimeters to several meters thick. They are of dark 295 color, massive or normally graded, with various grain-sizes depending on the position in the core. 10 turbidity deposits are present in the core, named $\mathrm{T} 1$ to $\mathrm{T} 10$, from top to bottom (Fig. $2972 \mathrm{a}, \mathrm{b})$. In the upper part of the core down to $5 \mathrm{~m}$, turbidity deposits are few, thin, fine-grained 298 and massive, with thickness ranging from $15 \mathrm{~cm}$ to $130 \mathrm{~cm}$. The upper one, T1, is $50 \mathrm{~cm}$ 
thick, massive and dark deposit at the top of the core. It covers unconsolidated brown hemipelagic mud which corresponds to the recent hemipelagic mud observed generally at the top of cores. Below $5 \mathrm{~m}$, turbidity deposits are thicker, coarse-grained, normally graded and more abundant. Below $10 \mathrm{~m}$, the whole core is made of turbidity deposits without intercalated hemipelagic mud. The last four turbidity deposits (T7 to T10) are significant not only for their thickness but also for their grain-size. These turbidity deposits are normally graded, with large size particles (up to $5 \mathrm{~cm}$ ) at the bottom and small size particles at the top.

24 tephra layers were identified in the first $8 \mathrm{~m}$ of the core. They are of dark color, sandy, a few $\mathrm{cm}$ thick, mainly interbedded in hemipelagic levels or more rarely in turbidity deposits. In the lower part of the core, tephra layers are scarce or totally absent.

19 levels of hemipelagic sediments can be recognized in the first $10 \mathrm{~m}$ (Fig. 2a, b); they have clear sand color and thickness ranging from $\sim 2-6 \mathrm{~cm}$ to $\sim 70 \mathrm{~cm}$. They are usually deformed or distorted, probably due to coring effects.

\subsection{Physical properties analyses}

Results from magnetic susceptibility and GRA (Gamma Ray Attenuation) density evidence adequate correlations between the two sets of values (Fig. 3). Turbidity deposits exhibit important variations in magnetic susceptibility (2500 to $\left.4000 * 10^{-5} \mathrm{SI}\right)$ and GRA density $\left(0.5\right.$ to $\left.2 \mathrm{~g} / \mathrm{cm}^{3}\right)$ (Fig. 3a). This is likely related to the coarse-grained characteristic of the basal part of the turbidity deposits leading to the poor ability of large size particles to ensure compaction and a lack of mineralogical sorting. Hemipelagic sediments show the largest amplitude in variations in physical properties with low values of about $1000-1500 * 10^{-}$

${ }^{5}$ SI for magnetic susceptibility and $<1.5 \mathrm{~g} / \mathrm{cm}^{3}$ for GRA density (Fig. 3a). A detailed view of section U1401A-1H2 (Fig. 3b) enables us to precisely analyze magnetic susceptibility 
variations at a centimeter scale. Six negative peaks are identified for hemipelagic parts of the

325 section, one main positive peak for turbidity deposit and six correspond to thin tephra layers 326 (Fig. 3b).

\subsection{Lithology}

Counting of 46 samples of tephra layers and turbidity deposits along the core were performed in order to characterize the lithological composition of the different volcanoclastic deposits (Fig. 2b). The most representative type of particles in the tephra layers are lava dome clasts. 16 different peaks can be recognized and their abundance is mostly higher than $30 \%$, with maximum values at about $\sim 96 \%$.

335 Abundance of pumice clasts ranges from 0 to $95 \%$ all along the core. 6 pumiceous peaks can 336 be identified: 4 in the shallow part of the core with pumice content of $88-95 \%$ (at a depth of 95, 163, 240 and $300 \mathrm{~cm}$ respectively) and 2 in its deeper part (at a depth of 700 and $800 \mathrm{~cm}$ ) showing pumice percentages of less than $50 \%$. Scoria clasts are in low abundance $(10-15 \%)$ except for three scoria peaks $(45-60 \%)$ at a depth of 688,713 and $766 \mathrm{~cm}$. Lithology of the major volcanoclastic turbidity deposits is dominated by lava dome clasts ( 80 to $98 \%$ ).

5.4. $\delta^{18} \mathrm{O}$ stratigraphy and ${ }^{14} \mathrm{C}$ dating

$\delta^{18} \mathrm{O}$ analyses on planktonic foraminifera (Globigerinoides ruber - white) of hemipelagic 345 sediments exhibit fluctuations ranging from $-2.52 \%$ (at $286 \mathrm{~cm}$ depth) to a maximum value of 0.07\% (at $650 \mathrm{~cm}$ depth; Fig. 2c). 3 remarkable points were chosen for ${ }^{14} \mathrm{C}$ dating (red dots in

347 Fig. 2c) : a steep negative peak of - $0.75 \%$ (at $290 \mathrm{~cm}$ depth), the maximum positive peak of $0.07 \%$ (at $650 \mathrm{~cm}$ depth) and the final last hemipelagic layer of the core of $-0.60 \%$ (at 965 
cm depth). For these three points, ${ }^{14} \mathrm{C}$ dating returned estimated ages of $8082 \pm 86$ years cal. BP, $24677 \pm 172$ years cal. BP and $36425 \pm 191$ years cal. BP respectively (after calibration with intcal 09.14c, Reimer et al, 2009).

\subsection{SEM observations}

Textures of pumice, scoria and lava dome clasts were obtained by BSE imaging (Fig. 4).

356 Clasts present large differences in size, shape and vesicularity. Lava dome clasts (Fig. 4a) are poorly vesiculated, with highly microcrystallized matrix glass. On the contrary, pumice clasts (Fig. 4b) are vesiculated with glassy matrix glass and thin bubble walls. Scoria clasts (Fig. 4c) are moderately vesiculated, with more contorted vesicle shape, larger bubble walls and more microcrystallized matrix glass than in pumice clasts.

\subsection{Geochemistry}

Major element compositions were measured in the main pumiceous and scoriaceous tephra layers and their matrix glasses exhibit few variations in composition (Table 1). For pumice clasts, silica content is centered at rhyolitic values of about $73-78 \mathrm{wt} \% \mathrm{SiO}_{2}$ (Fig. 5a) with a total alkali content of about $5 \mathrm{wt} \%$. Contrariwise, scoria clasts from tephra layers and turbidity deposits (T8, T9 and T10) show an extended compositional variability from andesite $\left(67 \mathrm{wt}^{\circ} \mathrm{SiO}_{2}\right)$ to rhyolite $\left(74 \mathrm{wt} \% \mathrm{SiO}_{2}\right)$ with $6-7 \mathrm{wt} \%$ alkali content (Fig. 5a).

\section{Discussion}


The chronostratigraphical record of core U1401A is first compared to a previous wellestablished tephrochronological one from a deep-sea sediment core CAR-MAR 4, collected $50 \mathrm{~km}$ northwest and downwind off Martinique Island (Fig. 1b) during the CARAVAL cruise in 2002 (Boudon et al., 2013). This core is in a steadier environment for sedimentation than that of the core U1401A, on a high point and outside the flow zones of debris avalanche and turbidity currents. For these reasons it may be used as a reference for our tephrochronological study in order to estimate the time period registered by the core U1401A. As the base of the core U1401A is located on the roof of the debris avalanche deposit related to the third flank collapse of Montagne Pelée, the tephrochronogical investigations will also provide constrains on a minimum age of the flank collapse.

CAR-MAR 4 is a $10.6 \mathrm{~m}$ long core, characterized, from top to bottom, by $7 \mathrm{~m}$ of continuous sedimentation with thick hemipelagic layers, tephra layers and no turbidity deposits followed by $3.6 \mathrm{~m}$ of disturbed and unstructured sedimentation (Boudon et al., 2013).

389 Only the first 7 meters were investigated for tephrochronological studies. CAR-MAR $4 \delta^{18} \mathrm{O}$ 390 results have already been correlated with a well-dated nearby deep-sea core (EN32-PC6, 391 Broecker et al., 1990). The correlation shows that CAR-MAR 4 covers the last 32 cal. ka BP 392 (Fig. 6). We can use it as a reference curve for U1401A because the two cores are spatially 393 close and analyses have been realized on the same planktonic foraminifera species and with 394 the same analytical protocol for both. Owing to the presence of thick turbidity deposits in the 395 core U1401A, to establish an adequate correlation with the CAR-MAR $4 \delta^{18} \mathrm{O}$ curve, it is 396 necessary to subtract the thickness of the turbidity deposits. This allows us to obtain a real 397 chronostratigraphic scale for hemipelagic deposits. 
A spectral analysis and a correlation between the two cores have been processed using the free software Analyseries (Paillard et al., 1996). This software enables us to compare our $\delta^{18} \mathrm{O}$ data with the selected reference CAR-MAR 4 curve by selecting and comparing a series

401 of calibration points between the two curves. From the calibration points, Analyseries realizes 402 a linear intercalibration to calculate the age of the intermediate points of the curve. It takes 403 into account the age and the depth of the two calibration points up and down the intermediary 404 one, and the depth of the intermediary point, according to the equation:

$$
\operatorname{Age}_{X}=\left[\left(\operatorname{age}_{A}-\operatorname{age}_{B}\right) /\left(\operatorname{depth}_{A}-\operatorname{depth}_{B}\right)\right]^{*}\left[\operatorname{depth}{ }_{X}-\operatorname{depth}_{A}\right]+\operatorname{age}_{A}
$$

where $\mathrm{X}$ is the intermediary point, $\mathrm{A}$ the upper calibration point and $\mathrm{B}$ the lower calibration point.

In the final age model (Fig. 6), the two curves are correlated with a coefficient of 0.936 and correlation returns a mean pelagic sedimentation rate of $22 \mathrm{~cm} / \mathrm{ka}$, consistent with that 410 known for the Grenada basin (Reid et al., 1996; Boudon et al., 2007). From the modelled 411 ages, the core U1401A covers a period from 0 to $\sim 36$ cal. $\mathrm{ka} \mathrm{BP}$, with a maximum $\delta^{18} \mathrm{O}$ value $412(0.07 \%)$ at about $25 \mathrm{cal}$. ka BP. The overlap of the two curves is clear especially in the first 413 part (0-8 ka). However, for recent ages, a small shift is evident between the two cores (Fig. 6): 414 the modelled ages of the core U1401A are younger than those of CAR-MAR 4. This proves 415 that the core U1401A recorded the largest temporal range, probably because of the presence 416 of a thick turbidity deposit (T1, $50 \mathrm{~cm}$ thick) at the top of the core that allowed the 417 preservation of the youngest and not compacted sediments, usually destroyed by drilling 418 processes. chronostratigraphy. The sampling interval for the core CAR-MAR 4 is constant at $10 \mathrm{~cm}$ 421 while the sampling interval could not be kept constant for the core U1401A. Sampling the core U1401A led to two types of problems: (1) the presence of numerous and thick turbidity 
deposits and (2) the low content of the planktonic foraminifera Globigerinoides ruber in

424 many samples. These problems can be explained by the particular position of the U1401 site,

425 located on the submarine flank of the volcano. As a result the site is more exposed to clastic

426 and clayey sedimentation related to on-land processes, which induce a decrease in biogenic

427 steady-state sedimentation. Secondly, the presence of thick turbidity deposits has a significant

428 impact on the sedimentary record of U1401A core. The correlation between the two cores is

429 lost when turbidity deposits are present (Fig. 6). In fact, some significant gaps occur, causing

430 a lack of thousands of years in the sedimentary record. A strong erosive power of turbidites

431 can probably be invoked during their deposition process.

432 Three ${ }^{14} \mathrm{C}$ dates were performed to obtain absolute ages on 3 key positions of the 433 U1401A core (Figs 2c, 6). They are roughly located at the top, the center and the bottom of 434 the core (respectively at $197,348.5$ and $488.5 \mathrm{~cm}$ turbidity deposits off depths). These 3 points have been selected as they represent a particular milestone in the evolution of the $\delta^{18} \mathrm{O}$ curve. In addition, dating the top and bottom of the curve allows us to obtain the entire coverage period of the core and an absolute age for the sediments located on the DAD. The most recent age obtained ( 8220 cal. ka BP) is well consistent with the model obtained with

$439 \delta^{18} \mathrm{O}$ analysis. It corresponds to a positive peak in the $\delta^{18} \mathrm{O}$ record. The second ${ }^{14} \mathrm{C}$ age of 44024677 cal. ka BP corresponds to the higher value of the $\delta^{18} \mathrm{O}$ obtained in the core U1401A. If 441 we compare with the CAR-MAR 4 curve where the higher value of the $\delta^{18} \mathrm{O}$ curve is obtained 442 at a more recent age $(\sim 18 \mathrm{ka})$, the maximum value of the $\mathrm{U} 1401 \mathrm{~A} \delta^{18} \mathrm{O}$ curve is probably too 443 high (Fig. 6a). This is likely related to the lack of points in the $\delta^{18} \mathrm{O}$ record due to the erosion 444 by turbidity density currents during the $17-24$ ka period where the maximum $\delta^{18} \mathrm{O}$ value is reached. The third ${ }^{14} \mathrm{C}$ age of $36425 \mathrm{cal}$. ka BP corresponds to the lowest point sampled in a 446 small hemipelagic deposit interbedded between T7 and T8 turbidity deposits and overlaying 447 the top of the debris avalanche deposit (T8 to T10) of the U1401A core. As this third age is 
obtained on the lowest hemipelagic level of the core but not really at its physical bottom, our

449 results of $\sim 36$ cal. ka BP represents a minimum age for the occurrence of the third flank 450 collapse of Montagne Pelée, that significantly contrasts with what was thought up to now.

451 Nevertheless below this point three thick turbidity deposits (T8 to T10) are present. They 452 overly the top of the debris avalanche deposit. No hemipelagic sediments are identified 453 between these turbidity deposits or at the top of the debris avalanche deposit. These 454 observations lead us to believe that it is likely that turbidity deposits T8 to T10 formed in a 455 short period of time directly after the flank collapse event.

6.2. Tephrochronology, stratigraphy and eruptive styles

Figure 7 shows the complete estimated chronostratigraphic model of the core U1401A.

24 tephra layers and 10 turbidity deposits have been recognized all along the core by cross correlation of photos observations, counting techniques and analysis of physical properties. The comparison of tephra record between the core U1401A and the core CAR-MAR 4 is 463 showed in Figure 6.

464 The core U1401A can be divided in three different units. In the first unit, 0-3 $\mathrm{m}$ in depth 465 (0 to 9 cal. ka BP), 2 turbidity deposits can be recognized (Fig. 7, T1=50 cm and T2=10 cm). The first turbidity deposit (T1) is located at the top of the core, covering the recent and not 467 compacted hemipelagic sediments. Its peculiar position allows it to be linked to the last period 468 of volcanic activity characterized by the last 1902-1905 and 1929-1932 dome-forming 469 eruptions. In addition, its lithology (prevalence of lava dome's clasts) is similar to that of on470 land pyroclastic density current deposits (Bourdier et al., 1989). This unit is also characterized 471 by the occurrence of 10 tephra layers (Fig. 7, red lines $=4$ pumice clast-rich levels and blue 472 lines $=6$ lava dome clast-rich levels) interbedded in the hemipelagic sedimentation. Such 
473 alternation of pumice clasts and lava dome clasts-rich levels is consistent with

474 tephrochronological results on the core CAR-MAR 4 (Fig. 6b, Boudon et al., 2013) and with

475 observations on on-land deposits that show the well-known alternation between dome-

476 forming eruptions and plinian or subplinian eruptions (P1 to P8 eruptions, Westercamp and

477 Traineau, 1983a, b; Traineau et al., 1989 Michaud-Dubuy, 2019). The residual glass of the

478 pumice clasts from these tephra layers has rhyolitic composition (about $75 \mathrm{wt} \% \mathrm{SiO}_{2}$ and 5

$479 \mathrm{wt} \% \mathrm{Na}_{2} \mathrm{O}+\mathrm{K}_{2} \mathrm{O}$ ) which is close to the composition of the residual glass of the pumice clasts

480 from on-land deposits (Fig. 5b). Furthermore their composition is clearly far from that of

481 Dominica island $\left(\mathrm{SiO}_{2} \sim 78 \mathrm{wt} \%, \mathrm{Na}_{2} \mathrm{O}+\mathrm{K}_{2} \mathrm{O} \sim 5-7 \mathrm{wt} \%\right.$, Balcone-Boissard et al., 2018) and

482 clearly excludes tephra originating from Dominica volcanoes, even though more

483 investigations have to be performed using trace elements proxies. We see that the record of

484 eruptive events is lower in the core U1401A than for the core CAR MAR4 and also for on-

485 land record (Fig. 6). This is due to the location of the site U1401 not in the axis of the main

486 local windward direction of the winds (westbound trade) and to the dispersion of the plumes

487 from plinian and subplinian eruptions or ash-clouds associated to block- and ash pyroclastic

488 density currents.

489 The second unit of the core, 3 to $8 \mathrm{~m}$ in depth ( 9 to $30 \mathrm{cal}$. ka BP) is characterized by 490 well-spaced turbidity deposits (Fig. 7, T3 to T6) in thick hemipelagic layers. Their thickness 491 varies from $10 \mathrm{~cm}$ (T4) to $120 \mathrm{~cm}$ (T5). Lithology of T3 and T5 shows the prevalence of lava 492 dome's clasts; they are probably linked with block- and ash pyroclastic density currents 493 associated to dome-forming eruptions. A total of 14 tephra layers can be documented in this 494 unit. Only 3 tephra layers enriched in lava dome clasts are recognized in the first half of the 495 second unit (Fig. 7, blue lines) whereas 11 tephra layers are present in the second half. 6 of 496 them are rich in dome clasts (blue lines), 2 rich in pumice clasts (red lines), whereas 3 of them 497 contain scoria clasts (green lines). In these tephra, the residual glass of scoria clasts is more 
basic than the residual glass of the pumice clasts $\left(\sim 65 \mathrm{wt} \% \mathrm{SiO}_{2}, \mathrm{Fig}\right.$. 5a), but we also observed some clasts that exhibit a more evolved composition $\left(\begin{array}{c}\sim 5 \\ \mathrm{wt}\end{array} \% \mathrm{SiO}_{2}\right)-$ see explanation in the next section. The lack of tephra records between 5 and $6.7 \mathrm{~m}$ in this unit may be related to a decrease in volcanic activity, or the set-up of thick turbidity deposits that eroded a part of the previously deposited sediments.

The third unit of the core, 8 to $15 \mathrm{~m}$ in depth (30 to $36 \mathrm{cal}$. ka BP) is almost exclusively characterized by thick turbidity deposits (T7 to T10). Their thickness varies from $140 \mathrm{~cm}$ (T7) to $230 \mathrm{~cm}$ (T8). Lithological results highlighted that these turbidity deposits are rich in lava dome's clasts but also in scoria clasts (about 10 to $20 \%$ ). The absence of hemipelagic sediments in this part of the core indicates a significant supply of volcanic products in a short 508 time interval.

\subsection{Origin of the scoria-rich levels}

Complete results on U1401A core show that the turbidity deposits and some of the tephra layers from the bottom of the core are rich in scoria clasts (up to $60 \%$ of the clasts in the sections between 680 and $820 \mathrm{~m}$ depth) of more basic composition $\left(\sim 65 \mathrm{wt} \% \mathrm{SiO}_{2}\right)$. The proportion of scoria clasts decreases progressively to the top of the core rarely being over a background content of $5 \%$ of clasts.

Based on tephrochronological study of the CAR-MAR 4 core (Fig. 6b) and on-land data,

518 Boudon et al. (2013) have proposed that abundant deposits of scoria flows of basaltic andesitic composition were generated after the second flank collapse event, estimated around $32 \mathrm{ka}$, whereas acid andesitic magma were emitted before this flank collapse event. These

521 changes in composition and eruptive style are explained by the decrease of the threshold 522 effect exerted by the volcanic edifice on the magma plumbing system allowing more basic 
523 and denser magmas to reach the surface (Pinel and Jaupart, 2005; Boudon et al., 2013,

524 Cassidy et al., 2015). This activity occurred over several thousand years, rapidly building a

525 new cone inside the horseshoe-shaped structure. This also shows that the magma production

526 was high just after the flank collapse and gradually decreased during the building of the new

527 cone and progressively exerted a new threshold effect on the plumbing system. The magma

528 production is then probably reduced for a few thousand years before resuming with the

529 production of more acidic and less dense magmas. The ages proposed for this period of 530 basaltic andesite emissions range between 32 cal. ka BP or more and 27 cal. ka BP. A period

531 of weaker magmatic activity occurs between 27 to 22.5 cal. ka BP prior to a new emission of 532 andesites from 22.5 cal. ka BP to present (Boudon et al., 2013).

533 The on-land relationship between the horseshoe-shaped structure of the second flank-

534 collapse and the scoria pyroclastic density currents were not clearly established as the scoria 535 pyroclastic density currents which resulted from column collapse of explosive eruptions, 536 covered all the flanks of the volcano inside and outside the horseshoe-shaped structures.

537 Considering 1) the estimated ages of the on-land scoria pyroclastic density currents 538 (Westercamp and Traineau, 1983a, b), the age of the tephra levels rich in scoria clasts in the

539 CAR-MAR 4 core band the ages obtained on the turbidity deposits and tephra level rich in 540 scoria clasts of the U1401A core; 2) the similar composition of the residual glass of these 541 scoria clasts in the cores and on-land, we can assume that all these deposits belong to the 542 same period of activity of Montagne Pelée and the production of basaltic andesites during this 543 period did not follow the second but the third flank collapse as the site U1401 is located on 544 the third DAD.

545 We also observe that even if the emitted magmas are dominantly basaltic andesites, they 546 can be associated with more evolved magmas of dacitic composition with rhyolitic glasses 547 (Fig. 5). This characteristic has already been evidenced on-land for these eruptions (Traineau 
et al., 1983; Bourdier et al., 1985) and explained by the presence of more superficial and small pocket of more evolved magmas within the "mushy" plumbing system impacted by the ascent of more basic magmas stored deeper (Pichavant et al., 2002). This magma mixing generally occurred at the beginning of the eruptive phases.

\subsection{Age of the third flank collapse and relationship with the volcanic activity}

554

Our results allow us to propose a significant shift in age of the third flank collapse from 9 ka to $\sim 36$ cal. ka BP.

Considering that the drilling operations of the core U1401A reach the top of the third

$\mathrm{DAD}$, and on the basis of the $\delta^{18} \mathrm{O}$ age model and on the ${ }^{14} \mathrm{C}$ ages we can consider that the age of $36425 \pm 191$ cal. ka BP obtained in the lowest level of hemipelagic mud is a minimum age for the third DAD and the corresponding flank collapse. But a series of turbidity deposits (T8 to T10) are recognized between the last dated hemipelagic mud and the top of the debris avalanche deposits. Thus it is possible to raise the question of the time interval separating this

$563{ }^{14} \mathrm{C}$ age from the true age of the flank collapse.

564 As previously proposed, the decrease of the load exerted by the third flank-collapse has 565 led to the production of scoria rich deposits of basaltic composition and to a high magma 566 production rate. This high magma production rate generated abundant scoria pyroclastic 567 density currents that entered the sea and evolved in turbidity currents. This explains the 568 abundance and the thickness of the turbidity deposits recognized at the base of the U1401A 569 core and on the debris avalanche deposit. This abundance of volcanic products generated after 570 the flank-collapse supports rapid deposition from the turbidity currents (T8 to T10). We can 571 consider that the time between the flank collapse and the ascent of more basic magmas is not 572 too long (probably not more than a few decades) and that the age of 36.425 cal. ka BP 
573 obtained on the hemipelagic mud covering these turbidity deposits is a minimum age not so

574 far from the true age of the debris avalanche setup.

\subsection{The recent eruptive history of Montagne Pelée}

Previous studies have described the eruptive history of Montagne Pelée as the succession of three different phases of construction of the volcanic edifice, separated by two flank collapses (Fig. 8a); the third flank collapse, is in fact included in the third stage of building (Le Friant et al., 2003; Boudon et al., 2005, 2007, 2013; Germa et al., 2011a). On the basis of on-land studies, the three different flank collapses had previously been dated at $127 \mathrm{ka}$

583 (Germa et al., 2011a) for the first one, $32 \mathrm{ka} \mathrm{(Boudon} \mathrm{et} \mathrm{al.,} \mathrm{2013)} \mathrm{and} 9 \mathrm{ka}$ (Le Friant et al., 2003), respectively for the second and the third one.

Nevertheless, the results of our study significantly modify the volcanological evolution of Montagne Pelée and allow us to submit a new evolution for the volcano (Fig. 8b). On-land, several rims of flank collapse structures have been identified (Fig. 11 of Le Friant et al., 2003 and Fig 1c). The rims resulting from the first flank-collapse structure are clearly identified, though its southern rim is not visible as it is covered by the products of the most recent volcano activity. Rims of the third flank collapse structures are clearly identifiable as they are

591 the most recent, but they are also partially covered by recent volcanic products. On the 592 contrary, the scars originating from the second flank collapse structure are not clearly visible 593 and remain questionable on the basis of on-land investigations. Recent offshore studies 594 following the IODP expedition 340 have shown that the DADs do not have the extension 595 previously proposed (Le Friant et al., 2015; Brunet et al., 2016). The large chaotic deposits 596 identified on seismic profiles and on bathymetry are deformed sediments pushed by the DAD 597 that stopped at the base of the submarine flank. It is difficult to distinguish the DADs of the 
598 first and the second event because they form a unique bulge at the base of the submarine flank 599 of the volcano (Fig 1b). On the contrary, the third DAD is clearly identified on the submarine 600 flank of the volcano with its lobe-shape and its hummocky morphology.

601 The question of the occurrence of three flank collapse events can thus be addressed in a 602 serious manner. The morphology and the distribution of the valleys indicate that the northern 603 rim of the first flank collapse structure exists. Its age of $127 \mathrm{ka}$ (Germa et al., 2011a) obtained 604 on two lava domes on each part of the rim is reliable. The third flank collapse is now also 605 clearly identified by the presence of submarine DADs, some remnants of hummock 606 morphology on-land and the rims of the horse-shoe shaped structure (Le Friant et al., 2003). 607 Its age is now confidently set at $\sim 36 \mathrm{ka}$ (this study). The time interval that separated the first $608(127 \mathrm{ka})$ from the third flank collapse $(\sim 36 \mathrm{ka})$ is in the order of $90 \mathrm{ka}$. Is this short period 609 enough to build a new cone destroyed by a second flank collapse and a third cone destroyed again by the third one? It is difficult to answer this question as the data we produce in this 611 study concern the last 40000 thousand years. However the magma production rate of 612 Montagne Pelée is, although significant, not very high and can be estimated at a few $\mathrm{km}^{3} / 10$ 613000 years for the last tens of thousands of years (Wadge, 1984, Michaud-Dubuy, 2019). We 614 can consider that the highest magma production rate occurred after the flank collapse event 615 dated now at $\sim 36 \mathrm{ka}$ over a period of 10000 years. An alternative to the already proposed 616 evolution of the volcano - that must be confirmed by on-land work and additional 617 tephrochronological investigations on other marine cores in the period between the first and 618 the "third" flank collapse - is that only two flank collapses occurred (Fig. 8b): the first one 619 at127 ka, and the last one at $36 \mathrm{ka}$. Though less voluminous, this last flank-collapse modified 620 the dynamics of the magmatic plumbing system, leading for a short period of time to the 621 ascent of more basic and denser magma than those emitted before the flank collapse. 622 Following this flank collapse, a lot of explosive eruptions produced scoria fall and density 
623 currents covering a large part of the volcano. Numerous turbidity currents were generated by

624 scoria density currents entering into the sea or by the remobilization of scoria density current 625 deposits, covering part of the submarine flank of Montagne Pelée. The eruptive activity was

626 high just after the flank-collapse and decreased progressively. The significant eruptive activity 627 rapidly involved the building of a new volcanic edifice which exerted a new threshold effect 628 on the plumbing system. The volcanic activity decreased and progressively a change in the composition of the emitted magmas occurred; more acidic magmas were generated giving rise to the alternance of plinian or subplinian events and dome-forming eruptions up to this day.

\section{Conclusions}

634

The detailed study of the core U 1401a located on the submarine flank of Montagne Pelée, on the hummocky deposit of the third debris avalanche (DAD 3) has improved our

637 knowledge of the eruptive history. It has allowed us to propose a minimum age of $\sim 36$ ka for 638 the last flank collapse. It also indicates that the volcanic activity can be modified in terms of magma production and in terms of magma composition after a flank collapse. Deeper and more basic magmas can erupt for a long time before a new cone exerts a threshold effect on

641 the plumbing system, reducing the magma production rate and changing the composition of 642 the emitted magmas. It also indicates that after a flank collapse, a lot of turbidity currents can 643 occur resulting in the offshore evolution of abundant pyroclastic density currents or the 644 remobilization of on-land deposits. It also shows that a sole core does not enable the 645 reconstruction of all the eruptive history of a volcano for a given period. The core U1401 646 located on the western submarine flank of Montagne Pelée is well located for the study of the 647 post flank-collapse activity and the pyroclastic density currents as well as tephra layers. 
648 Abundant turbidity deposits have an significant erosive power, destroying part of the lower

649 deposits, but can also preserve recent and not compacted hemipelagic sediments, generally 650 not observed, as was the case for the upper recent turbidity deposits. The core CAR MAR 4 is 651 best located to study tephra layers as it is on a high point without erosion and closer to the 652 direction of the winds (East-West) in the troposphere. But a lot of tephra are dispersed to the 653 East as the eruptive column for Plinian eruptions reaches the stratosphere where the wind 654 direction is generally West-Easterly. A core located to the east of Montagne Pelée will allow 655 us to complete the eruptive history of the volcano.

656

657

658

659

660

Acknowledgments

661 We thank the captains, officers, crews of the R/V Joides Resolution and the IODP-340 662 scientific mission. Major element analyses at the microprobe facility benefited the support of 663 M. Fialin and N. Rividi (Service CAMPARIS). Oxygen stratigraphy analysis benefited the 664 support of N. Labourdette (UPMC). Imaging at SEM was helped by Omar Boudouma 665 (Sorbonne Université). We thank INSU, NERC, ANR-13-BS06-0009 for funding. ${ }^{14} \mathrm{C}$ dating 666 were performed at LMC14 laboratory (Artemis program). We also thank E. Lebas for her 667 participation and help in the acquisition of planktonic foraminifera samples.

\section{References}


Allan, A.S.R., Baker, J.A., Carter. L., Wysoczanksi, R.J., 2008. Reconstructing the Quaternary evolution of the world's most active silicic volcanic system: insights from an $\sim 1.65$ Ma deep ocean tephra record sourced from Taupo Volcanic Zone, New Zealand. Quat. Sci. Rev. 27(25-26): 2341-2360.

Balcone-Boissard, H., Boudon, G., Blundy, J.D., Martel, C., Brooker, R.A., Deloule, E., Solaro, C., Matjuschkin, V., 2018. Deep pre-eruptive storage of silicic magmas feeding Plinian and dome-forming eruptions of central and northern Dominica (Lesser Antilles) inferred from volatile contents of melt inclusions Contrib. Mineral. Petrol. 173:101, https://doi.org/10.1007/s00410-018-1528-4.

Boudon, G., Lajoie, J., 1889. The 1902 péléean deposits in the Fort Cemetery of St. Pierre, Martinique: a model for the accumulation of turbulent nuées ardentes. In: Boudon, G., Gourgaud, A. (Eds), Montagne Pelée. J. Volcanol. Geotherm. Res. 38:113-129.

Boudon, G., Le Friant, A., Villemant, B., Viodé, J.-P., 2005. Martinique. In: Lindsay, J.M., Robertson, R.E.A., Shepherd, J.B., Ali, S. (Eds.), Volcanic Atlas of the Lesser Antilles. Seismic Research Unit, The University of the West Indies, Trinidad and Tobago, WI, pp 65-102.

Boudon, G., Le Friant, A., Komorowski, J.-C., Deplus, C., Semet, M.P., 2007. Volcano flank instability in the Lesser Antilles Arc: diversity of scale, processes, and temporal recurrence. J. Geophys. Res. 112, B08205.

Boudon, G., Villemant, B., Le Friant, A., Paterne, M., Cortijo, E., 2013. Role of large flank collapses on magma evolution of volcanoes. Insights from the Lesser Antilles Arc. J. Volcanol. Geotherm. Res. 263:224-237. http://dx.doi.org/10.1016/j.jvolgeores. 2013.03.009. 
695 Bourdier, J.-L., Gourgaud, A., Vincent, P.M., 1985. Magma mixing in a main stage of

696

697

698

699

700

701

702

703

704

705

706

707

708

709

710

711

712

713

714

715

716

717 formation of Montagne Pelée: the Saint Vincent-type scoria flow sequence (Martinique, F.W.I.). J. Volcanol. Geotherm. Res. 25:309-332.

Bourdier, J.-L., Boudon, G., Gourgaud, A., 1989. Stratigraphy of the 1902 and 1929 nuée ardente deposits, Montagne Pelée, Martinique. In: Boudon, G., Gourgaud, A. (Eds): Mount Pelée. J. Volcanol. Geotherm. Res. 38:77-96.

Bouysse, P., Westercamp, D., Andreieff, P., 1990. The Lesser Antilles Island Arc. Proceedings of the Ocean Drilling Program, Part B: Scientific Results 110:29-44.

Broecker, W.S., Klas, M., Clark, E., 1990. Accelarator mass spectroscopic radiocarbon measurements on foraminifera shell from deep-sea cores. Radiocarbon 32(2):119-133,

Brunet, M., Le Friant, A., Boudon, G., Lafuerza, S., Talling, P., Hornbach, M., Ishizuka, O., Lebas, E., Guyard, H. and IODP Expedition 340 science Party, 2016. Composition, geometry, and emplacement dynamics of a large volcanic island landslide offshore Martinique: From volcano flank-collapse to seafloor sediment failure? Geochem. Geophys. Geosyst .16, doi:10.1002/2015GC006034.

Cassidy, M., Watt, S.F.L., Talling, P.J., Palmer, M.R., Edmonds M., Jutzeler, M., WallPalmer, D., Manga, M., Coussens, M., Gernon, T., Taylor, R.N., Michalik, A., Inglis, E., Breitkreuz, C., Le Friant, A., Ishizuca, O., Boudon, G., McCanta, M.C., Adachi, T., Hornbach, M.J., Colas, S.L., Endo, D., Fujinawa, A., Kataoka, K.S., Maeno, F., Tamura, Y., Wang, F., Ishizuka, O., and Shipboard Science Party, 2015. Rapid onset of mafic magmatism facilitated by volcanic edifice collapse. Geophys. Res. Lett. 42, 4778-4785, doi:10.1002/2015GL064519.

Coussens, M., Wall-palmer, D., Talling, P.T., Watt, S.F.L., Cassidy, M., Jutzeler, M., Clare, M.A., Hunt, J.E., Manga, M., Gernon, T.M., Palmer, M.R., Hatter, S.J., Boudon, G., 
Endo, D., Fujinawa, A., Hatfield, R., Hornbach, M.J., Ishizuka, O., Kataoka, K., Le Friant, A., Maeno, F., McCanta, M., Stinton, A.J., 2016. The relationship between eruptive activity, flank collapse, and sea level at volcanic islands: A long-term ( $>1 \mathrm{Ma})$ record offshore Montserrat, Lesser Antilles. Geochem. Geophys. Geosyst., doi:10.1002/2015GC006053.

Deplus, C., Le Friant, A., Boudon, G., Komorowski, J.-C., Villemant, B., Harford, C., Ségoufin, J., Cheminée, J.-L., 2001. Submarine evidence for large-scale debris avalanches in the Lesser Antilles Arc. Earth. Planet. Sci. Lett. 192:145-157.

D’Orbigny, A.D. 1839. Foraminifères, in de la Sagra R., Histoire physique, politique et naturelle de l'ile de Cuba.Arthus Bertrand, Paris 224p.

Engwell, S.L., Sparks, R.S .J., Carey S. 2014. Physical characteristics of tephra layers in the deep sea realm: the Campanian Ignimbrite eruption. In: Austin, W. E. N., Abbott, P. M., Davies, S. M., Pearce, N. J. G., Wastegard, S. (Eds). Marine Tephrochronology. J. Geol. Soc. London, Special Publication, 398, 47-64. http://dx.doi.org/10.1144/SP398.7.

Fichaut, M., Marcelot, G., Clocchiatti, R. 1989. Magmatology of Mt. Pelée (Martinique, F.W.I.). II: petrology of gabbroic and dioritic cumulates. In: Boudon, G., Gourgaud, A. (Eds): $\quad$ Mount $\quad$ Pelée. J. Volcanol. Geotherm. Res. $38: 171-18$.

Germa, A., Quidelleur, X., Lahitte, P., Labanieh, S., Chauvel, C., 2011a. The K-Ar 738 Cassignol-Gillot technique applied towestern Martinique lavas: A record of Lesser Antilles arc activity from 2 Ma to Mount Pelée volcanism. Quaternary Geochronology $6: 341-355$ 
741 Germa, A., Quidelleur, X., Labanieh, S., Chauvel, C., Lahitte, P., 2011b. The volcanic evolution of Martinique Island: Insights from $\mathrm{K}-\mathrm{Ar}$ dating into the Lesser Antilles arc migration since the Oligocene. J. Volcanol. Geotherm. Res. 208:122-135.

744 Hughen et al., 2004. Marine 04 marine radiaacarbon age calibration, 0-26 cal kyr BP. Radoicarbon 46:1059-1086.

Jenning, A., Thordarson, T., Zalzal, K., Stoner, J., Hayward, C., Geirsdotti, A., Miller, G., 2014. Holocene tephra from Iceland and Alaska in SE Greenland Shelf Sediments. In: Austin, W. E. N., Abbott, P. M., Davies, S. M., Pearce, N. J. G., Wastegard, S. (Eds). Marine Tephrochronology. J. Geol. Soc. London, Special Publication, 398, 157-193. http://dx.doi.org/10.1144/SP398.6.

Kutterolf, S., Schindlbeck, J. C., Robertson, A. H. F., Avery, A., Baxter, A. T., Petronotis, K., \&Wang, K.-L. (2018). Tephrostratigraphy and provenance from IODP Expedition 352, Izu-Bonin arc: Tracing tephra sources and volumes from the Oligocene to recent. Geochemistry,Geophysics, Geosystems,19,150-174. https://doi.org/10.1002/2017GC007100

Labanieh. S., Chauvel, C., Germa, A., Quidelleur, X., Lewin, E., 2010. Isotopic hyperbolas constrain sources and processes under the Lesser Antilles arc. Earth. Planet. Sci. Lett. 298:35-46.

Lacroix, A., 1904. La Montagne Pelée et ses Eruptions. Masson ed., Paris, 662 pp.

760 Le Friant, A., Boudon, G., Deplus, C., Villemant, B., 2003. Large scale flank-collapse during the recent activity of Montagne Pelée, Martinique, FWI. J. Geophys. Res. 108, B1, 2055. 

of marine sediments adjacent to Montserrat, Lesser Antilles volcanic arc. J. Geol. Soc. London165:279-289.

766

767

768

769

770

771

772

773

774 775

Le Friant, A. et al., 2015. Submarine record of volcanic island construction and collapse in the Lesser Antilles arc: First scientific drilling of submarine volcanic island landslides by IODP Expedition 340. Geochem. Geophys. Geosyst. 16:420-442. doi:10.1002/2014GC005652.

Lowe, D.J., 2014. Marine tephrochronology: a personal perspective. In: Austin, W. E. N., Abbott, P. M., Davies, S. M., Pearce, N. J. G., Wastegard, S. (Eds). Marine Tephrochronology. J. Geol. Soc. London, Special Publications, 398, 7-19. http://dx.doi.org/10.1144/SP398.11.

Martin-Kaye, P.H.A., 1969. A summary of the geology of the Lesser Antilles. Overseas Geology and Mineral Resources 10(2):172-206.

Michaud-Dubuy, A., 2019. Dynamique des éruptions pliniennes: réévaluation de l'aléa volcanique en Martinique. Thèse Université de Paris, 200 pp.

Paillard, D., Labeyrie, L., Yiou, P., 1996. Macintosh program performs time-series analysis. Eos, Transactions, Am. Geophys. Union, 77:379 (Abstract).

Paterne, M., Guichard, F., Labeyrie, J. 1988. Explosive activity of the SouthItalian volcanoes during the past 80000 years as determined by marine tephrochronology. J. Volcanol. Geotherm Res., 34:153-172, http://dx.doi.org/10.1016/0377-0273(88)90030-3.

Paterne, M., Labeyrie, J., Guichard, F., Mazaud, A., Maitre, F. 1990. Fluctuations of the Campanian explosive volcanic activity South Italy during the past 190,000 years, as determined by marine tephrochronology. Earth Planet. Sci. Lett., 98:166-174, http://dx.doi.org/10.1016/0012-821X(90)90057-5 
Paterne, M., Guichard, F., Duplassy, J.-C., Siani, G., Sulpizio, R., Labeyrie, J., 2008. A 90,000-200,000 yrs marine tephra record of Italian volcanic activity in the Central Mediterranean Sea. J. Volcanol. Geotherm. Res. 177:187-196.

Perret, F., 1937. The Eruption of Mt. Pelée 1929-1932. Carnegie Inst. Washington, Publ. 458, $126 \mathrm{pp}$.

Pichavant, M., Martel, C., Bourdier, J., Scaillet, B. 2002. Physical conditions, structure, and dynamics of a zoned magma chamber: Mount Pelée (Martinique, Lesser Antilles arc). J. Geophys. Res. 107, doi:10.1029/2001JB000315.

Pinel, V., Jaupart. C., 2005. Some consequences of volcanic edifice destruction for eruption conditions. J. Volcanol. Geotherm. Res. 145, 68-80.

Reid, R.P., Carey, S.N., Ross, D.R., 1996. Late Quaternary sedimentation in the Lesser Antilles island arc. Geol.Spc. Am. Bull. 108:78-100.

Reimer, P.J. et al., 2009. IntCal09 and Marine09 radiocarbon age calibration curves, 0-50,000 years cal BP. Radiocarbon 51(4):1111-1150.

Roobol, M.J., Smith, A.L.,1976. Mount Pelée, Martinique: A pattern of alternating eruptive slyles. Geology 4(9): 521-524.

Shane, P., 2000. Tephrochronology: a New Zealand case study.Earth-Science Reviews 49(14): $223-259$.

Shane, P., Sikes, E.L., Guilderson. T.P., 2006. Tephra beds in deep-sea cores off northern New Zealand: implications for the history of Taupo Volcanic Zone, Mayor Island and White Island volcanoes. J. Volcanol. Geotherm. Res. 154:276-290.

Sigurdsson, H., Carey, S.N., 1981. Marine tephrochronology and Quaternary explosive volcanism in the Lesser Antilles arc. In: Self S., Sparks R.S.J. (eds) Tephra Studies. Springer, Dordrecht, 75: 255-280. 
811

812

813

814

815

Smith, A.L., Roobol, M.J., 1990. Mt Pelée, Martinique; A Study of an Active Island-arc Volcano. Geol. Soc. Am. Memoir 175105 p.

Talling, P., Masson, D.G., Sumner, E.J., Malgesini, G., 2012. Subaqueous sediment density flows: Depositional processes and deposit types. Sedimentology 59(7):1937-2003.

Traineau, H., Westercamp, D., Coulon, C., 1983. Mélanges magmatiques à la Montagne Pelée (Martinique). Origine des éruptions de type Saint-Vincent. Bull. Volcanol. 46 :243-269.

Traineau, H., Westercamp, D., Bardintzeff, J.-M., Miskovsky, J.-C., 1989. The recent pumiceeruptions of Mt. Pelée volcano, Martinique. Part I: Depositional sequences, description of pumiceous deposits. J. Volcanol. Geotherm. Res. 38:17-33.

Trofimovs, J., Amy, L., Boudon, G., Deplus, C., Doyle, E., Fournier, N., Hart, M.M.B., Komorowski, J.-C., Le Friant, A., Lock, E., Pudsey, C., Ryan, G., Sparks. R.S.J., Talling, P.J., 2006. Submarine pyroclastic deposits formed at the Soufrière Hills Volcano, Montserrat (1995-2003): what happens when pyroclastic flows enter the ocean? Geology, 34 (7):549-552.

Wadge, G., 1984. Comparison of volcanic production rates and subduction rates in the Lesser Antilles and Central America. Geology 12:555-558. http://dx.doi.org/10.1130/ 00917613

Wall-Palmer D., Coussens M., Talling P.J., Jutzeler M., Cassidy M., Marchant M. Palmer M.R., Watt S.F.L., Smart C.W., Fisher J.K., Hart M.B., Fraass F., Trofimovs J., Le Friant A., Ishizuka O., Adachi T., Aljahdali M., Boudon G., Breitkreuz C., Endo D., Fujinawa A., Hatfield R., Hornbach M.J., Kataoka K, Lafuerza S., Maeno F., Manga M.,Martinez-Colon M., McCanta M., McManus J.,Morgan S., Saito T., Slagle A., Stinton A.J., Subramanyam K.S.V., Tamura Y., Villemant B., Wang F., 2014. Late Pleistocene stratigraphy of IODP Site U1396 and compiled chronology offshore of 
south and south west Montserrat, Lesser Antilles, Geochem. Geophys. Geosyst ., 15, doi: 10.1002/2014GC005402.

Wall-Palmer, D., Hart, M.B., Smart, C.W., Sparks, R.S.J., Le Friant, A., Boudon, G., Deplus, C., Komorowski, J.-C., 2012. Pteropods from the Caribbean Sea: variations in calcification as an indicator of past ocean carbonate saturation. Biogeosciences 9(1):309-315. doi: 10,5194/bg-9-309-2012.

Weller, D.J., Miranda, C.G., Moreno, P.I., Villa-Martínez, R., Stern, C.R. 2015. Tephrochronology of the southernmost Andean SouthernVolcanic Zone, Chile; Bull Volcanol. 77: 107 DOI 10.1007/s00445-015-0991-2

Westercamp, D., Traineau, H., 1983a. Carte géologique au 1/20 000 de la Montagne Pelée, avec notice explicative. In: B.R.G.M. (Ed.), Orléans.

Westercamp, D., Traineau, H., 1983b. The past 5,000 years of volcanic activity at Mt. Pelee martinique (F.W.I.): implications for assessment of volcanic hazards. J. Volcanol. Geotherm. Res. 17:159-185. http://dx.doi.org/10.1016/0377-0273(83)90066-5.

Westercamp, D., Pelletier, B., Thibault, P.-M., 1990. Carte géologique de la Martinique à 1/50 000 avec notice explicative. B.R.G.M. eds, Orléans.

Wulf, S. W., Kraml, M., Brauer, A., Keller, J., Negendanl, J. F. W. 2004. Tephrochronology of the $100 \mathrm{ka}$ lacustrine sediment record of Lago Grande di Monticchio (southern Italy). Quarternary International, 122, 7-30, http://dx.doi.org/10.1016/j.quaint.2004.01.028

\section{Figure captions.}

Figure 1. a) Geodynamic setting of the Lesser Antilles volcanic arc; Predicted bathymetry from Smith and Sandwell (1997). Contour interval is $500 \mathrm{~m}$; b) Swath bathymetry of the west coast of Martinique with the position of the bulge, the SLD and the 

U1401 is located on Deposit 3 and consists of a $900 \mathrm{~m}$ transect with four holes (C, A, B, D from East to West); c) Detail of the west flank of Montagne Pelée volcano marked by horseshoe shaped structures deriving from flank collapses. First flankcollapse structure is labeled in red, the second in green and the third in yellow (from Le Friant et al, 2003).

Figure 2. a) Photo of the first section $(1 \mathrm{H})$ of the core U1401A. Hemipelagic mud (brown squares, H) appears in clear beige color; turbidites (yellow squares, T1 to T5) are more characterized by a dark brown color and significant thickness. Tephra layers (orange lines, $\mathrm{t}$ ) have features similar to turbidites and low thickness; this makes it difficult to simply recognize them to the naked eye. A more detailed description of tephra layers has been done by counting operation; b) Synthetic log of the whole core U1401A. In brown: turbidites (T1 to $\mathrm{T} 10)$; in beige: hemipelagic mud; in orange: tephra layers (t). Abundance of volcanic fragments in each tephra layer and in volcanoclastic turbiditic deposits obtained from counting operations: in green scoria, in red pumices and in blue lava dome clasts; Six peaks of pumices can be recognized along the core, four in the first $300 \mathrm{~cm}$ and two others in the deep part of the core at depth of 700 and $800 \mathrm{~m}$. Two peaks of scoria are found at about 700 m. Lava dome clasts prevail all along the core with percentages rarely going lower than $20 \%$; c) Isotopic $\delta^{18} \mathrm{O}$ and ${ }^{14} \mathrm{C}$ results on core $\mathrm{U} 1401 \mathrm{~A}$ : in blue $\delta^{18} \mathrm{O}$ results, In red: ${ }^{14} \mathrm{C}$ dating for the three marker points at $197,348.5$ and $488.5 \mathrm{~cm}$ in the core). $\delta^{18} \mathrm{O}$ values exhibit variations from $-2,52$ to $0,07 \%$, with high values in the deep part of the hole and isotopic maximum recorded at about $650 \mathrm{~cm}$ in depth. 
885 Figure 3. a) Correlation between GRA density and magnetic susceptibility data along the core U1401A; on the right side simplified log of the core: in brown turbiditic deposits ( $\mathrm{T} 1$ to $\mathrm{T} 10)$, in grey scoria layers and in beige sections parts of the core with prevalence of hemipelagic mud (Hem.); b) Detail of magnetic susceptibility data for the section $1 \mathrm{H} 2$ of the core. Six tephra layers, one turbiditic deposit and six hemipelagic mud can be recognized in the section following the positive and negative peaks in data.

892

893 Figure 4. SEM images of three representative volcanic fragments with a magnification of x35 894 and $\mathrm{x} 75$ for the top images and $\mathrm{x} 300$ for the more detailed lower images. a) Lava dome clasts: characterized by low vesicularity and highly microcristallized matrix glass; b) Pumice clasts: usually well vesiculated, characterized by large matrix glass and no microlite; c) Scoria clasts: with well-developed thicker matrix glass, partially microcristallized.

899

Figure 5. a) Evolution of the $\mathrm{SiO}_{2}$ content of volcanic clasts (matrix glasses) along depth in 901 the core U1401A. Single point measurements on matrix glass of different glass shards are represented. Pumice clasts (red circle) present one main compositional range b between 70 and $79 \mathrm{wt} \% \mathrm{SiO}_{2}$, whilst scoria clasts (green circle) exhibit amore basic compositional range, between 64 and $70 \mathrm{wt} \% \mathrm{SiO}_{2}$. Within the scoriarich levels, some more silicic clasts of similar composition as the pumice clasts are present (light red diamonds); b) $\mathrm{K}_{2} \mathrm{O}$ vs. $\mathrm{SiO}_{2}$ diagram of matrix glass of the glass shards of the core U U1401 and little matrix glass from U 1401B, C and D. The domains of residual glass from on-land deposits are also reported: pumices (blue) 
and scoria clasts (purple) from Montagne Pelée (Boudon et al., 2013) and pumices from the neighboring island of Dominica (orange) (Balcone-Boissard et al., 2018).

913 Figure 6: a) Modeled age of the core U 1401 A and correlation with the core CAR-MAR 4 (Boudon et al., 2013). The curve in calibrated age for the core U14101A is issued from the correlation with the core CAR-MAR 4. The final modeled age returns a bottom core age of $36425 \mathrm{cal}$ yr BP and a mean sedimentation rate of $\sim 22 \mathrm{~cm} / \mathrm{ka}$ coherent with the values known for the basin. The model returns some important gaps of $\sim 6 \mathrm{ky}$ in the sedimentary record due to the erosive power of turbidites; b) Comparison of tephra records in between the core U1401A (top) and the core CARMAR 4 (bottom). In U1401A red lines: pumice tephra; green lines: scoria tephra; blue lines: lava dome clast tephra; brown rectangles: turbiditic deposits. In CARMAR 4 all red lines indicate tephra levels in the core. The tephra records in between the two cores is consistent, with the same change in tephra typology from scoria clasts in the bottom of the cores to lava dome and pumice clasts at the top of the cores.

Figure 7: Ages of tephra layers depending on the depth in the core. In red pumice layers, in green scoria layers and in blue lava dome clast layers. Finally 24 tephra layers are recognized with: alternating of pumice and lava dome clasts in the first $10 \mathrm{cal}$. ka $\mathrm{BP}$, prevalence of dome-forming eruptions in the period 13-16 cal. ka BP and

932 Figure 8 : The recent volcanic history of Montagne Pelée: toward a new model of evolution. Comparison with previous works. 

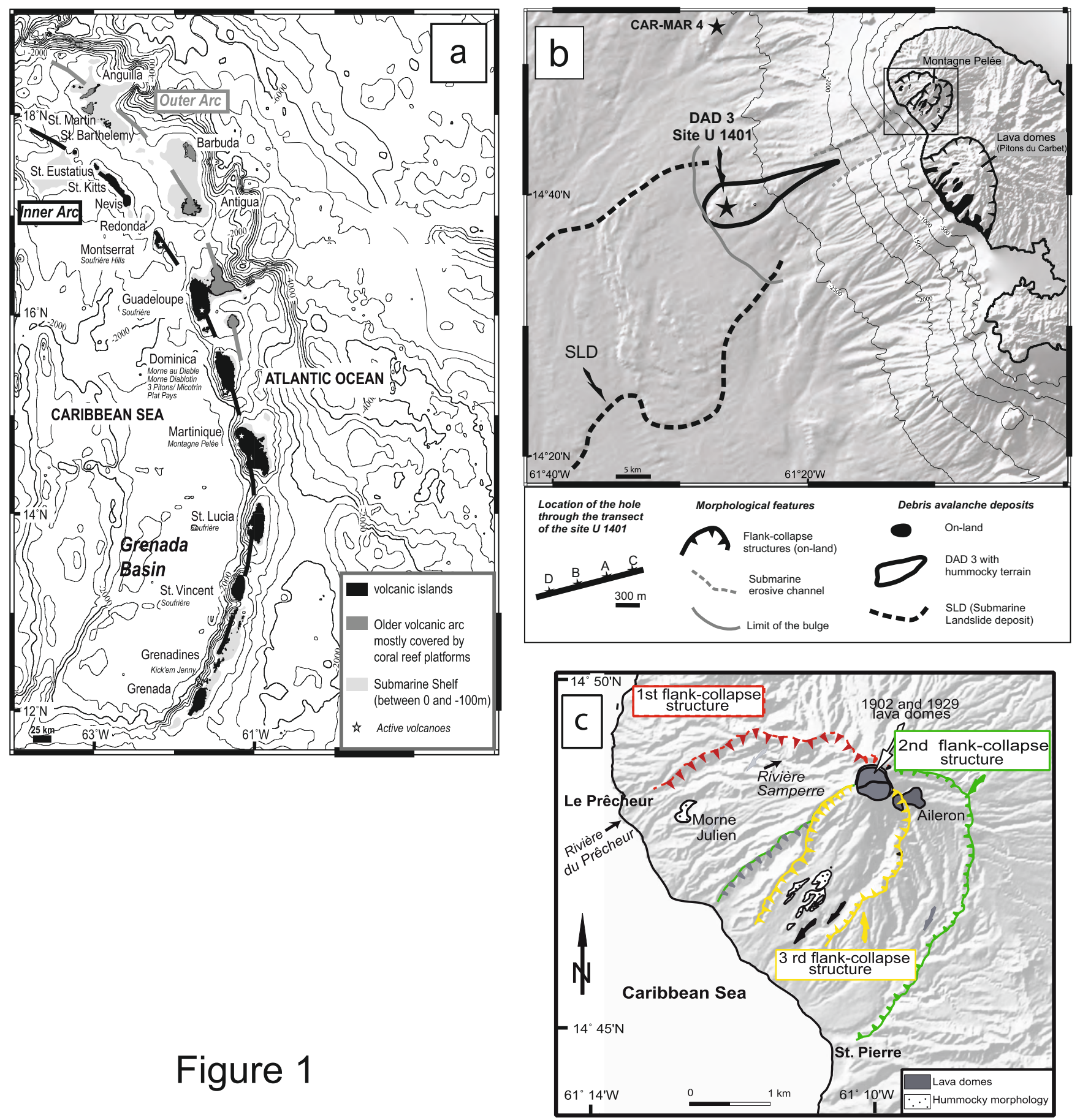

Figure 1 


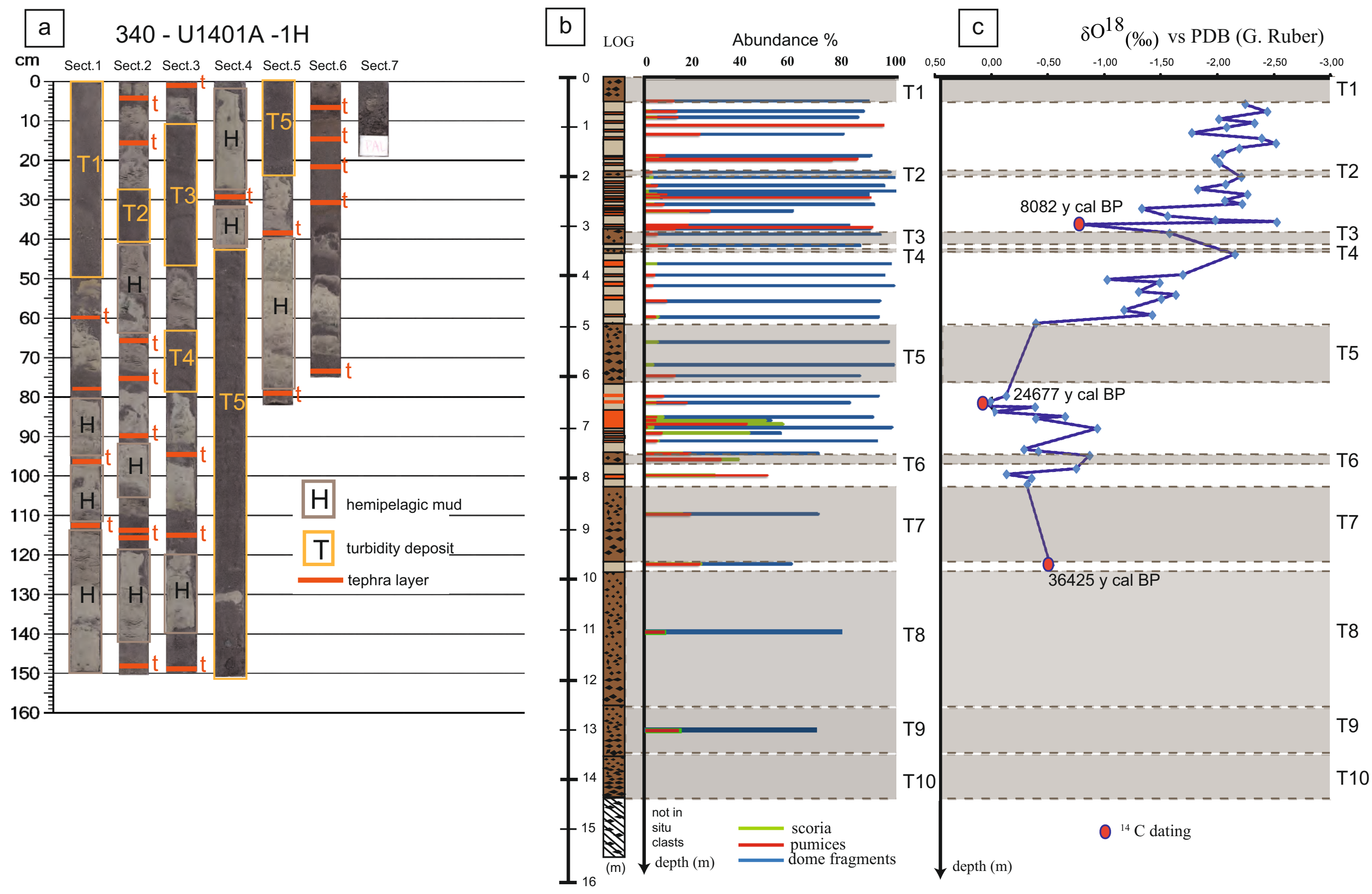

Figure 2 

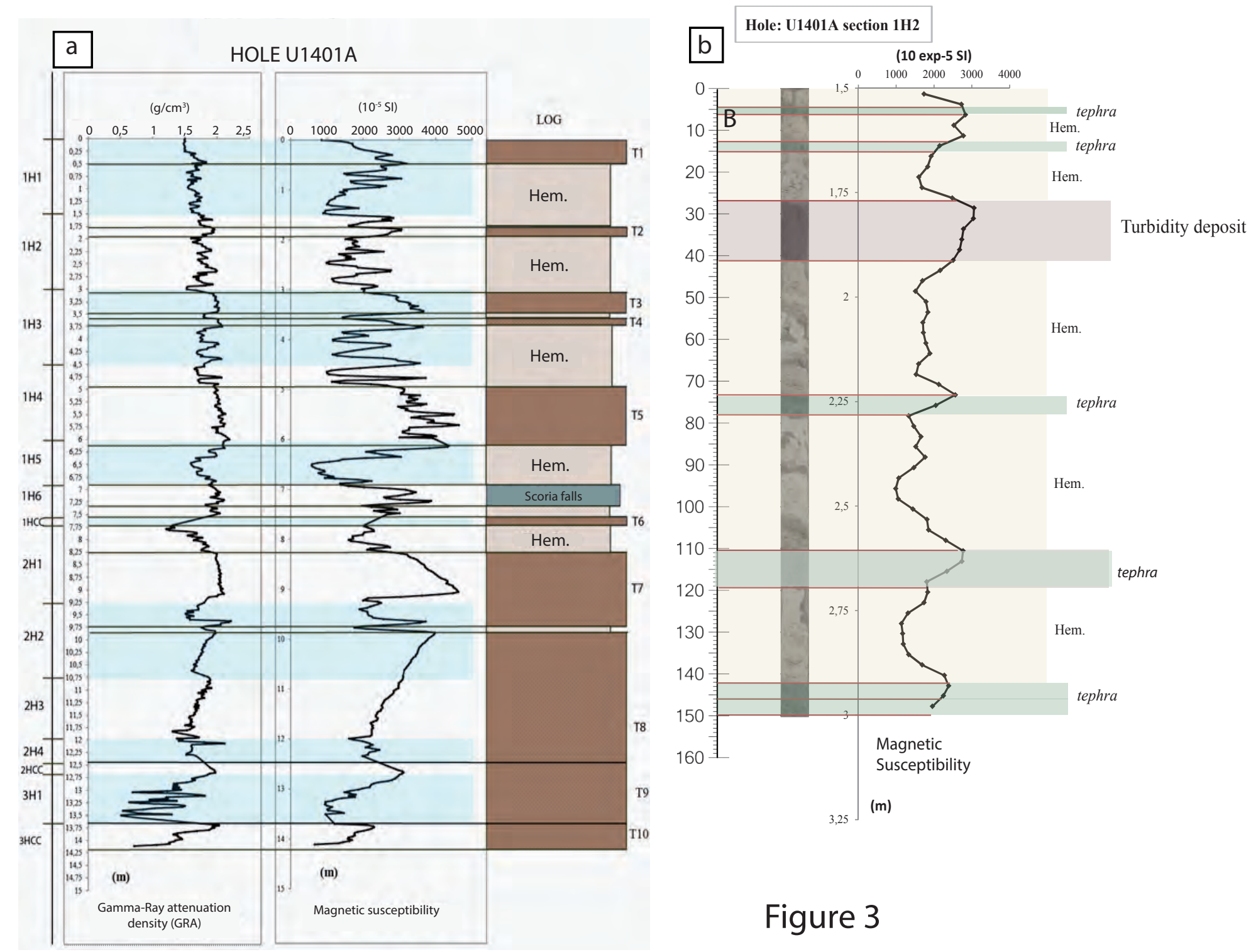

Figure 3 

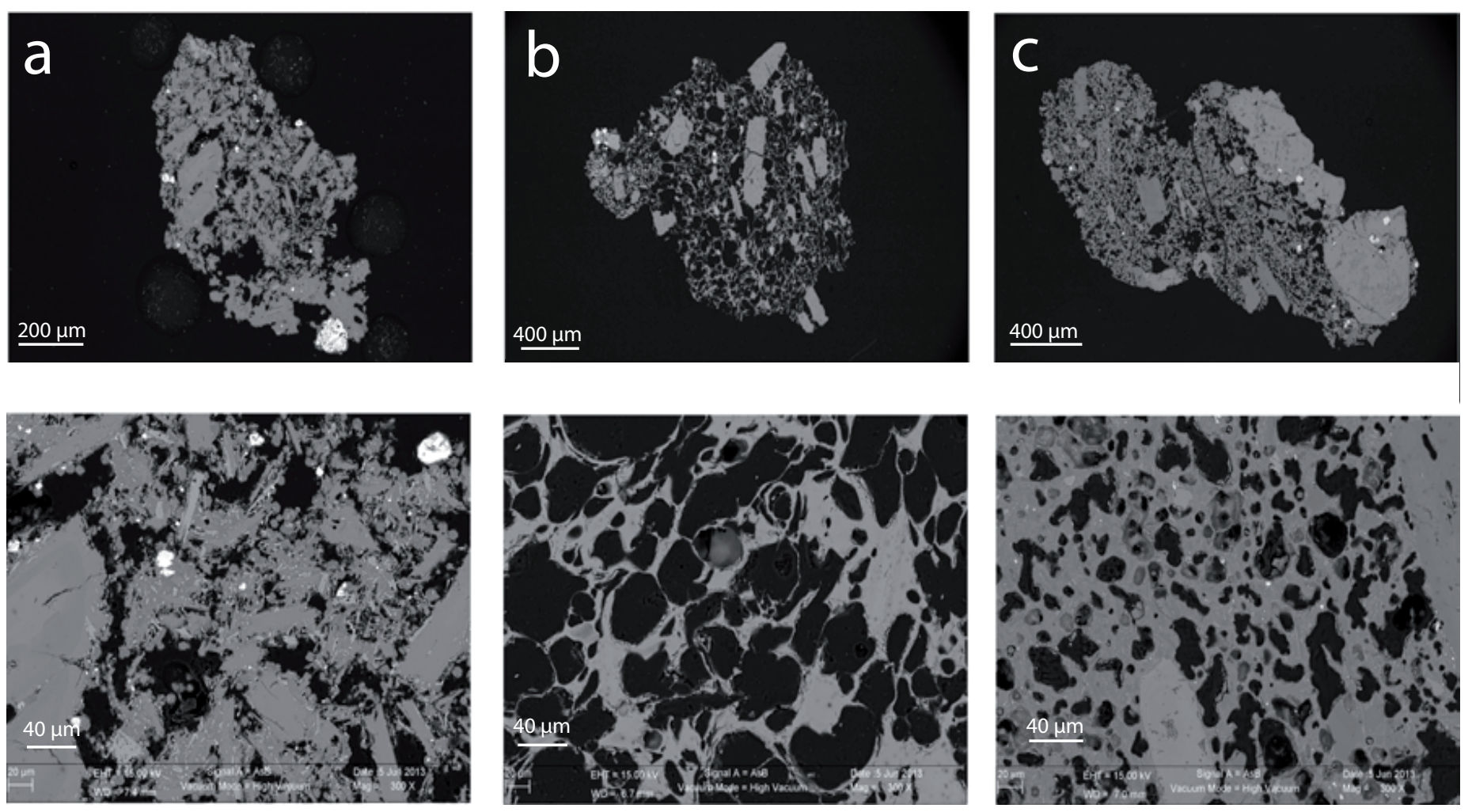

Figure 4 


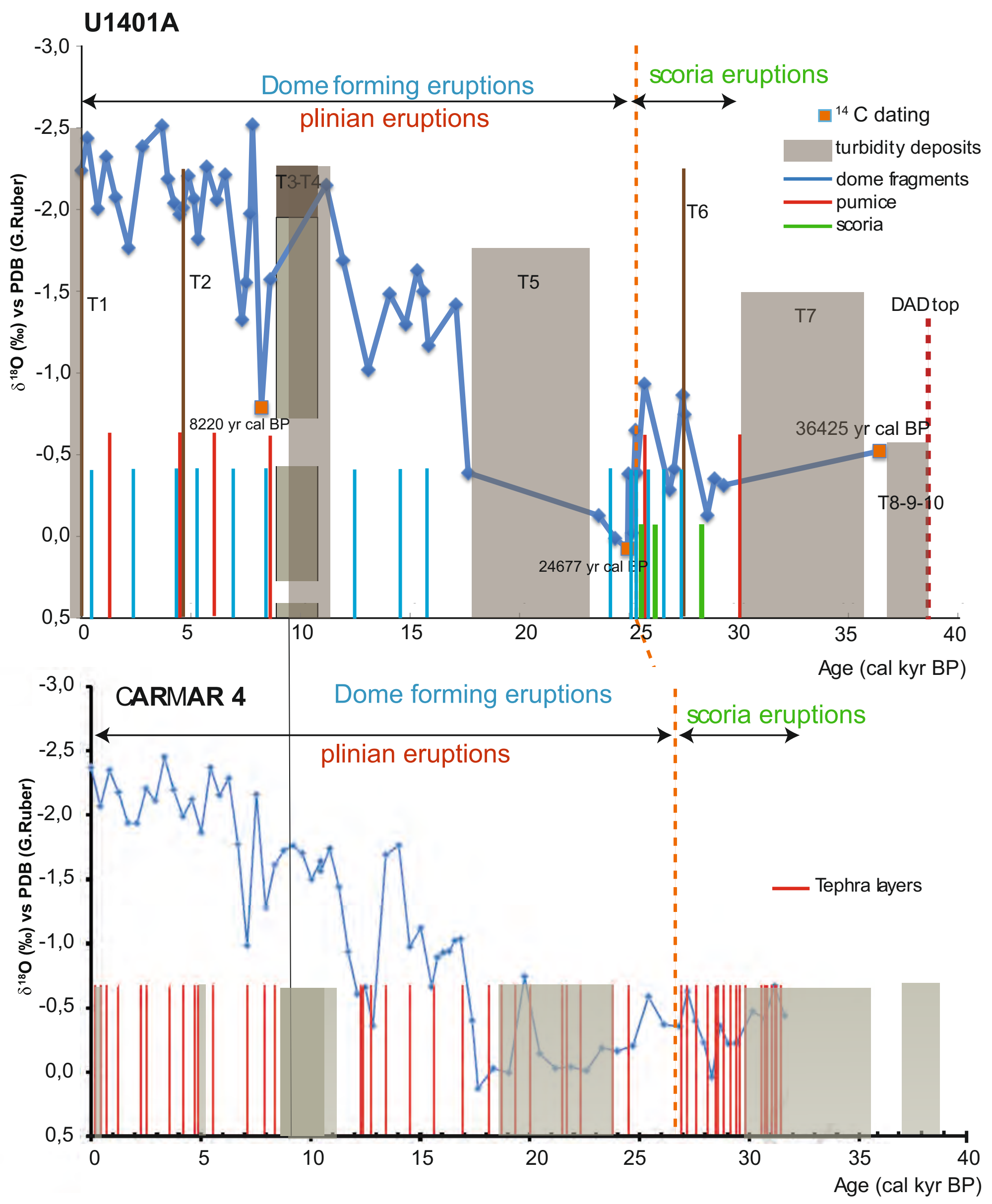

Figure 6 


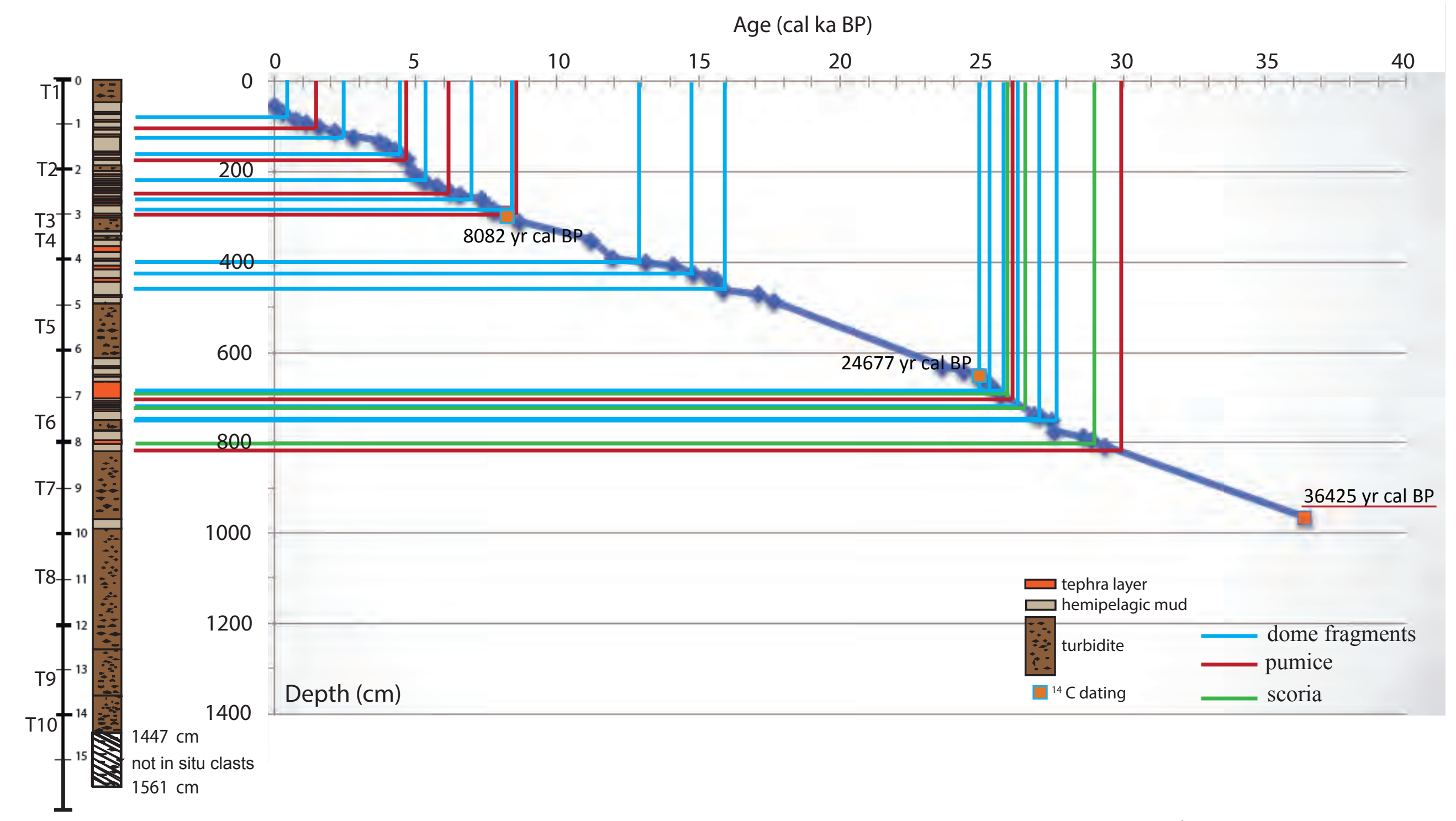

Figure 7 
